\title{
TAMÁs NAGY*
}

\section{Law, Literature and Intertextuality}

\begin{abstract}
Most of the contemporary scholarships of both literature and law categorize the coincidences and overlaps between an author's literary work and his or her legal career, a given literary period and the same historical era of law and jurisprudence or between innumerable pieces of literature and the texts of the law merely as things of no real interest, curious facts that are not worthy of detailed academic analysis. While a point of view of this kind has its reasons the aim of the following paper is to change this attitude to a certain extent. In my opinion instead of talking about the "death of law and literature" we should consider the possibilites of (re)opening new ways of research for law and literature studies that may provide mutual benefits to both the representatives of legal and literary sciences. Hereinafter I will try to show why and how exploring the intertextual connections between the texts of law and those of literature seems to me the most fruitful endeavour to connect law and literature to each other.
\end{abstract}

Keywords: law and literature, interdisciplinarity, intertextuality, law as intertext, critique of contemporary jurisprudence and literary criticism, Dostoevsky, Kafka, Kleist, Hajnóczy, Cover, Ferguson, Ziolkowski

"In the last analysis, everything that happens to writersgood or bad-forms a part of their literary destiny (and they have no other). Tout est á boutir á un livre, says Mallarmé. Everything in the world exists to be turned into a book." Danilo Kis ${ }^{1}$

\section{Introduction}

Kleist, Hoffman and the Allgemeines Landrecht, Heine, Stendhal and the Code Napoleon, Dostoyevsky and the 1864 Russian legislation, Kafka and the Strafgesetz from 1852, the Penal Code of Austria-Hungary. Authors, their works and modern legal history's texts of privileged status. Codes that-by fate or accident-have made it into the text of a writing or in some cases, an entire life's work, the reception of which, however, has gone by without much attention being paid to the significance and the meaning of these connections either by literary or by legal scholarship.

Just consider the above-mentioned examples: the remark of Stendhal, that in the course of writing The Charterhouse of Parma he read the Code Napoleon each morning to make sure that the novel's style could stay "sufficiently dry and objective", 2 is well known as a sort of bon mot, just as it is well known of Hoffman that he was a high court judge, or that Kleist, Heine and Dostoyevsky were committed supporters of the codifications of their era.

* Associate professor, University of Szeged Law School, H-6722 Szeged, Rákóczi tér 1.

E-mail: nagyt@juris.u-szeged.hu

Author's note: I am more than grateful to my friend and colleague Prof. Olivia Radics-pronounced as [rodit']-(University of Baltimore School of Law) without whose invaluable help this text could have never (never ever, no chance) been ready in time (see: deadlines).

${ }^{1}$ Kiš, D.: Introduction to The Anatomy Lesson. Trans. R. Manheim. In: Homo poeticus: essays and interviews. Manchester, 1996. 11.

2 Babits, M.: Az európai irodalom története (reprint) [History of European Literature]. Budapest, 1991. 495. 
And just as with regards to Dostoyevsky it is almost always mentioned that he was to suffer the processes of the Russian criminal justice system, up until the last minute mitigation of his death sentence to one of forced labor, so the Kafka-reception's pieces don't fail to mention either that the author's days were filled with legal work performed as a functionary of the Worker's Accident Insurance Institute for the Kingdom of Bohemia in Prague.

So many historical facts, biographical and sociographical details which might serve as starting points for drawing suspicions and assumptions with regards to the nature of the relationship between the texts and the worlds of literature and law (whatever these latter words might in fact mean), but in and of themselves are hardly capable of anything more: we cannot draw more audacious conclusions merely from these circumstances. Accordingly, the contemporary scholarships of both literature and law categorize the coincidences and overlaps between the author's literary work and his or her legal career, a given literary period and the same historical era of law and jurisprudence or-and let's draw our attention primarily to this for the purposes of the present writing-between innumerable pieces of literature and the texts of the law, as they appear in the codes, judicial decisions and other legal documents, merely as things of no real interest, curious facts that are not worthy of detailed academic analysis.

\section{What is wrong with these scholarships?-actually, nothing, just}

The aversion and distance of literary scholarship is understandable. Modern literary theory and criticism, as opposed to the positivist approach of comte-ian origin, championed by Hyppolite Taine, has, throughout the $20^{\text {th }}$ century, gradually and ever so vigorously refused to apply the kind of interpretation of literary texts that have reference to the so-called 'reality'. In today's literary discourse, any and all interpretations treating the text as a derivation of the author's biography or psychology (the taine-ian la race, le milieu et le moment ${ }^{3}$ ) or intention seem irredeemably obsolete.

Nevertheless what is surprising: those approaches that insist on the suspension of referential interpretation and instead opt for a (close) textual analysis of literature, and the intertextual analyses fueled by the theoretical energies of these, seem to accept only in exceptional cases the validity of law's texts as intertexts in the course of the interpretation of literary works. ${ }^{4}$ On occasion postmodern literary scholarship may provide counterexamples-what's more, has even gone as far as asking the more general question of whether there is an irrelevant context in the course of the interpretation of literary texts ${ }^{5}$,

3 Taine, H. A.: Introduction to the History of English Literature. In: Eliot, C. W. (ed.): Prefaces and Prologues to Famous Books. Charleston (SC), 2007. 412.

${ }^{4}$ For a review of the basic literary principles of the theory of intertextuality the Hungarian reader might want to see the thematic issue of Helikon periodical. Intertextualitás. [Intertextuality] Helikon, 42 (1996) 1-2. Otherwise for a general overview see: Allen, G.: Intertextuality. LondonNew York, 2000.

5 Szilasi, L.: Nyakvers (irodalmilag releváns kontextus-e az angol jog?) [Neckverse (is English law a relevant context from a literary perspective?)] In: Miért engedjük át az ácsnak az épitkezés örömét [Why let the carpenter have the joy of building operations]. Budapest, 1994. 57-67. In this work Szilasi interprets the last poem of Bálint Balassi, the psalm translated on his death bed, starting with the words Ah Deus immensum clemens miserere perecantis, in a new light, using the context of the English legal custom-of which a central moment was the reading out aloud of this particular psalm-that provided for the possible avoidance of the execution of the death penalty in certain cases. 
but despite this, the written and spoken (or put down as spoken: witness statements, victim reports, oral pleadings/requests etc.) language of the law usually stays outside the realms of intertextuality. In the background of this denial there stands the following conviction: the representatives of literary studies with regards to the interpretation of literary texts treat with suspicion-and often with good reason-any approach to the realm of literature that tries to apply "outside" viewpoints and the value judgments included therein. Opposing such types of analysis, Milan Kundera said that they tear away the studied texts (Kundera of course refers primarily to novels, but his statements can be applied to other types of literary genres as well) from the "large context of literary history" and thus degenerate the act of interpretation into cheap (biographical, psychological, political, theological and so on) explanation or in the words of the Czech author: "kafkology". 6

I find that this approach somewhat limits the range of intertextual research, as it hinders the recognition that literary and legal texts can often enter into a fruitful dialogue that is often laden with new meanings.

With regards to Kundera's statement (and actually contrary to it), I believe not only that through intertextual investigation certain episodes of legal history may fit into the web of the grand connections of literary history, but also that this sort of dialogue's mutual-that is, it can be enjoyed both by literary and by legal scholarship-benefit appears where we don't expect it beforehand. Not only is this true of those works (and their interpretations) where the role of the interplay between legal and literary texts in the process of creating aesthetic experience and meaning is apparent right away (let's just recall Michel Foucault's remark that Greek drama can be read as the theatrical version of Greek legal history ${ }^{7}$ ), but also in the case of those where the mechanisms of text connections take more invisible forms; where the catharsis- and meaning-creation works in somewhat more mysterious textual ways.

The presence of legal themes (the portrayal of the legal profession, the justice system and certain legal problems) or the unraveling of the possible opinions of the authors with regards to the law, the legal system and its questions should not signify the ending point of those interpretation possibilities that include a legal viewpoint. I find those types of analysis that try to show how a legal text may influence the formation of the text (the narrative structure, plotline, style, choice of words, sentence structure etc.) of a piece of literary

As Szilasi says: "the guilty literate is saved from death through his ability to read that what is written". The more general question is similarly fundamental for law and literature studies as well, namely whether literary and legal texts can form an intelligent context for each other, whether the study of texts in one group can be of benefit to the interpretation of texts in the other group.

${ }^{6}$ See Kundera, M.: The Castrating Shadow of Saint Garta. Trans. Linda Asher. In: Testaments Betrayed. An Essay in Nine Parts. New York, 1996. 42-44.

${ }^{7}$ As Foucault says Oedipus the King is "a kind of compendium of the history of Greek law". He reads certain dramas by Sophocles, especially the Antigone and the Electra, as a sort of theatrical ritualization of legal history. In his interpretation what we see here is the most important moment of the spreading of Greek democracy summarized in a dramatic form: the story of the process through which the people acquire the right to judgement and to provide justice and can turn this against those who had previously disposed of this right. For more on this see Foucault, M.: Truth and Juridical Forms. Trans. Robert Hurley et al. In: Power (The Essential Works of Foucault 1954-1984. Vol. 3.) New York, 2000. 17-33. Another great example of a similar analysis can be found in: Simon A.: A törvény Szophoklész Antigonéjában [The law in Sophocles' Antigone]. Iustum Aequum Salutare 3 (2007) 2, 71-93. 
fiction, or in other words, how it becomes part of the poetical tools operating the text in question, and how and to what extent it determines the process of interpretation, an entire valid area of research. Solely for the purposes of illustration-without any sort of analysislet me mention a few obvious examples.

On the stories of Heinrich von Kleist-both with regards to style and structure-a visible influence can be detected, formed by those Landrecht style handbooks that strictly determined the language use, formalities and structure of those judicial pre-decision materials the construction of which was among the tasks of Kleist as an employee of the chamber of treasury of Königsberg. ${ }^{8}$ Thus, the patterns of codified Prussian law often served as organizing principles in the stories of the oeuvre, from the relentless efforts at precision resulting in strict stylistic and editorial consequences to the kleistian sentence structures.

The language use and formalities of the contemporary Russian criminal process (with regards to which Dostoyevsky talked directly of his opinion and ideas in $A$ Writer 's Diary ${ }^{9}$ ) have a central role in several novels of Dostoyevsky-especially in The Brothers Karamazov. In the trial act the narration becomes rather repetitive-thus evoking the repetition that is present with regards to the same events in the witness statements, trial records, and summaries prepared by the judge. Moreover, the structure and text of the novel presents the same problems-and thus forces the reader to face these-, which could and still cannot be solved satisfactorily by legal scholarship, namely the difficulties relating to the narration of past events (stories) and the possibilities of reconstruction with regards to the conscience of the free-willed subject in the modern era. ${ }^{10}$

In Franz Kafka's case-whose story, The Stoker can also be seen as a sort of Kleistparaphrase and therefore it is a remarkable piece of that "exciting intertextual tangle" becomes Péter Hajnóczy's The Stoker in Hungarian literature ${ }^{12}$, not only his interest in the

8 See Ziolkowski, T.: The Mirror of Justice: Literary Reflections of Legal Crisis. Princeton (NJ), 1997. 194-214.

9 See Murav, H.: Russia's Legal Fictions. Ann Arbor (MI), 1998. 125-155.

10 Did everything happen the way the novel originally narrates or in some other way, like howin the course of the trial-the lawyers approach it and record it, with their own perspectives and notions? As Richard Weisberg says "the lawyers 'create' Dmitri, they create the motives for the crime, they create the "history of a family". What is the relationship between the two stories, between "reality" and narrated reality, between a man and his intentions and the creature constructed by the lawyers' notions and his will or consciousness? Dostoyevsky's text foretells the questions of legal realism, contemporary cognitive psychological studies and narrative jurisprudence. See Weisberg, R.: The Codification of Western Law and The Poethics of Disclosure. Cardozo Studies in L. and Literature, 6 (1994) 157; Guthrie, C.-Rachlinski, J. J.-Wistrich, A. J.: Inside The Judicial Mind. Cornell Law Review, 86 (2001) 777; Nagy, T.: Narratív tematika a kortárs amerikai jogelméletben. [Narrativity in contemporary American jurisprudence.] Acta Universitatis Szegediensis, Acta Juridica et Politica, Tomus LXIII., Fasc. 15., Szeged, 2003.

${ }^{11}$ Cserjés, K.: Da capo al fine. Hajnóczy Péter egy hátrahagyott novellájáról. [Da capo al fine. A short story by Péter Hajnóczy from the bequest.] Tiszatáj, 57 (2003) 5, 113-123.

12 It is my conviction that the impact of the textual world, the language use-its style, expressions, sentence structure, narrative techniques, structure etc.-of certain documents of the law and jurisprudence of Hungarian socialism on Hajnóczy's treatment of text is definitely more pronounced than what has been established by the secondary literature referring to the life-work so far. Perhaps it was János Marno, another writer, who had the most precise feeling with regard to the direct relationship between the texts. "A police report, a document relating to the author's first difficult 
era's legal debates can be documented (and placed in the context of the penal reform debates of the dying monarchy present in In the Penal Colony or The Trial), but it is clear that one of the main points of reference and intertexts for The Trial is the Strafgesetz of 1852. ${ }^{13}$ What's more: the fact that in a secular world the now not originally sinful man's anthropological status includes the presumption of innocence, and thus becomes a part of the contemporary reader's horizon of expectations, and how this fact in turn affects the aesthetic impact of the novel would deserve an independent analysis, just like the question as to how much the "threat that oozes from the kafkian sentence structure"14 could be lead back to the text and narrative technique of bureaucracy and law-and doing this without dislodging Kafka from the domain of aesthetics and without fulfilling the purpose of kafkology-"replacing Kafka with the Kafkologized Kafka"15-under the burden of the curse of Kundera.

In sum: the intertextual signs and references-direct or indirect, that is, through the works of other authors-found in literary texts often lead the reader to the textual world of the law. This of course does not mean that by reading a literary work read through the lenses of law-in the spirit of the "violent" nature and "meaning-killer" practice of law ${ }^{16}$-we wish to exclusively concentrate on the meaning in terms of the law. The intention is just the opposite and aims to find such new interpretations that by reading together the legal and literary text-a synoptic approach, if you like-could enrich the number of possible interpretations as well as our literary and legal knowledge.

The aversion and distance of the legal science can also be explained, nevertheless I do not find this approach of mainstream jurisprudence to literature neither wise, nor defendable.

In the United States, ever since its birth with Langdell, the principle aim of legal science and legal theory, a discipline that became independent and thus respectable rather late and only following a lengthy struggle, has always been the connection to and possible influence of the professional legal practice, the actual jurisdiction: in other words, to establish a position, a framework, in which, as "the legislation of legislation and the court

incident with the Kádár-regime, from 1964. Well, the 'language', concise 'style' of this official report describes, evokes the incident with an infernal humor against which reason basically cannot compete [...]. The heroic text formation of Hajnóczy [...] confronts with the 'psycho-social demons' of both the external nivellation and the internal deconstruction, destruction, by 'following' their strategy and playing on their tone. (Let me add that he could never surpass the 'level' of the police report)". Marno, J.: Amióta most már egyre inkább [Ever since it's been more indeed]. Hitel, 3 (1990) 5, 5657. As-let me add yet another example-István Örkény never wrote anything "better" than the text of a police document that bears the title Jelentés Örkény István iró gépkocsi vezetöi engedélyéröl [Report on writer István Örkény's driving license], dated 3rd November 1959, Budapest. Rubicon, 16 (2004) 8-9, 76. Furthermore, I am also convinced that on the texts of countless literary works from the era of socialism in the former Soviet Bloc countries basicly the same impact could be detected.

13 See Ziolkowski, T.: op. cit. 214-240, and 'Franz Kafka: The Trial'. In: Dimensions of the Modern Novels: German Texts and European Contexts. Princeton (NJ), 1969. 37-67. Furthermore: Nagy, T.: “A per" mint burleszk, avagy releváns kontextus-e az Osztrák-Magyar büntetőjog? ['The Trial' as burlesque or is Austro-Hungarian criminal law a relevant context?] In: Mezey, B. (ed.): Jogi kultúrák, processzusok, rituálék és szimbólumok [Legal cultures, processes, rituals and symbols]. Budapest, 2006. 250-266.

14 Birnbaum, M. D.: Esterházy-Kalauz [Esterházy-Guide]. Budapest, 1991. 156.

15 Kundera: op. cit. 42.

16 See Cover, R.: The Supreme Court 1982 Term, Foreword: Nomos and Narrative. Harvard Law Review, 97 (1983) 4. and Violence and the Word. Yale Law Journal, 95 (1985-1986) 1601. 
of courts" the normative and-borrowing on the ideal of natural sciences-the predictive features of jurisprudence could succeed. ${ }^{17}$ Parallel to this endeavor, members of the American legal academia seemed to deny that tradition of the legal profession and way of thinking in which law and literature were inseparably intertwined and that was called by Robert A. Ferguson the "configuration of law and letters". ${ }^{18}$ The denial of the heritage of the American enlightenment-partly as a counter-effect of the tradition's strength-brought with itself the abandonment of the viewpoints of literature (and humanities in general) and the relevant theoretical reflection. ${ }^{19}$ The interdisciplinary turn ${ }^{20}$ of American legal theory in the 1960s did not change this scenario in any meaningful way: from among the numerous "law and ..." trends-despite all their institutional popularity (meaning: within the academia and especially the elite universities)-only the economic analysis of the law ("law and economics"), with its quasi natural science-like and seemingly objective probings, could reach acceptance. ${ }^{21}$ But if we look at legal science as a whole, the dominance of the late $19^{\text {th }}$ century ideals and goals (autonomy and commitment to practice) and their tradition, together with a dominance of constitutional legal themes and doctrinal analysis, is still prevalent, despite the fact that a langdellian 'dream come true' becomes more and more obviously illusory and impossible. ${ }^{22}$

17 See for example Schlag, P.: Normativity and the Politics of Form. In: Schlag, P.- Campos, P. F.- Smith, S. D.: Against the Law. Durham and London, 1996. 29-99. Richard Posner is even more stern in his criticism of the representatives of American jurisprudence, calling them a bunch of "kibitzers and scolds". Posner, R.: The Problematics of Moral and Legal Theory. Cambridge (MA), 1999. 194.

18 Ferguson, R. A.: Law and Letters in American Culture. Cambridge (MA), 1984. Nagy, T.: Jog és irodalom: kezdetek és eszmények. [Law and literature: beginnings and ideals.] Iustum Aequum Salutare, 3 (2007) 2, 57-69.

19 Certain exceptions aside. With a different emphasis and in different ways, but the following authors also establish a connection between law and literature-and with the same breath, between the American enlightenment and modern "law and literature" research: Wigmore, J.: List of Legal Novels. Illinois Law Review, 2 (1908), 574; Cardozo, B. N.: Law and Literature. In: Law and literature and other essays and addresses. New York, 1931. 3-52; Fuller, L. L.: The Case of the Speluncean Explorers. Harvard Law Review, 62 (1949) 616.

20 See Posner, R: The Decline of Law as an Autonomous Discipline. 1962-1987. Harvard Law Review, 100 (1987), 761.

${ }^{21}$ Moreover: the objectives of interdisciplinary approaches are not always that clear either. Perhaps the most obvious example of this is the posnerian program of "law and literature", in which the author seemingly joins one movement, but in such a way that it is at the same time an attempt at a destructive criticism of the very same approach, and-as a latent function of his dissertation-he attempts to realize objectives that stand in clear opposition to the original intentions of these studies, namely the defense of the autonomy of law and legal science (and also the safeguarding of the hegemonic position of the economic analysis of law in the world of interdisciplinarity). See also Balkin, J. M.: The Domestication of Law and Literature. Law and Social Inquiry, 14 (1989), 787; Nagy, T.: Néhány eljárás: Kafka-olvasatok a jogirodalomban [A few processes. Kafka-readings in jurisprudence]. In: Josef K. nyomában (-jogról és irodalomról-) [The path of Josef K. (-on law and literature-)]. Máriabesnyő-Gödöllö, 2010. 85-121.

22 Schlag, P.: Normative and Nowhere to Go. In: Laying Down the Law: Mysticism, Fetishism, and the American Legal Mind. New York-London, 1996. 17-41, and The Evaluation Controversy. Id. at $60-76$. 
As for modern continental legal science-mainly as the result of the heritage of Roman law and German legal science-, it has always been dominated by the dogmatic analysis of statutory law with special regards to the conceptual-analyst and concept-constructionist procedures that revive some of the $19^{\text {th }}$ century traditions (and the inherent views about the aims of jurisprudence and the role of legal academics) of the pandectists. ${ }^{23}$ Neither these actions of the legal science, nor the major trends of contemporary European legal theory (legal positivism, the Anglosaxon analytical legal philosophy, or the socio-legal [system] theories) do not provide an adequate opportunity to explore the mutual relationship between legal and literary texts. The difference and separateness of law and literature (and the arts in general) is most heavily emphasized by those theories that build on a socio-theoretical basis and that distinguish functional difference as the primary feature of contemporary societies: they show two entirely separate field of social activity, and any relationship between the two can/should only be characterized by "presupposing their existential-functional difference". ${ }^{24}$

To present such a relationship pattern as the "one and only" not only covers up the elementary mutual dependence of law and narrative(s), explored by Robert Cover in his influential essay, ${ }^{25}$ as well as the fact that legal activity-just like literary activity-is primarily an effort to create, explain, and often manipulate texts and the stories they tell, it also leaves in the shade that legal and literary texts-starting from the Bible and several other documents from antiquity, through Cicero, and then two thousand years later the orations of Daniel Webster and the decisions of the Supreme Court, the works of Kleist, Dostoyevsky, Kafka or Hajnóczy-are all parts of a text universe the pieces of which are in constant interaction and dialogue with each other. ${ }^{26}$

23 This is of course a simplification, but it does not touch the subject of this writing in substance. The same goes for defining "legal dogmatics" as a decidedly practical activity. For the problems with regards to the definition of the notion and territory of "legal dogmatics", see Szabó, M. (ed.): Jogdogmatika és jogelmélet [Legal dogmatics and legal theory]. Miskolc, 2007.

${ }^{24}$ This viewpoint-starting from the "reflected difference-experience"-is stated in: Cs. Kiss, L.: Megjegyzések a jog és a művészet viszonyához. [Notes on the connections between law and the arts]. Iustum Aequum Salutare, 3 (2007) 2, 13-18. I believe that Cs. Kiss' questions-reflecting his doubtsdo not touch the studies of the intertextual relations between law and literature. If to answer the question as to what kind of products can either law or literature provide through its own functionspecific operation for the other as a playing field of legitimate examination, then the answer is simple: texts.

25 Cover, R.: op. cit.

${ }^{26}$ Not to mention that: the texts of the law and especially the texts of court decisions are evidently of an intertextual or more precisely, of an hypertextual nature: they become one from stories narrated by witness statements, the texts of high court decisions (themselves hypertextual) and the commentaries of statutes and relevant commentaries. The concept of hypertextuality is applied to literary works by Genette, but I do not see why it could not be used with regards to legal texts as well. He talks of a textual relationship in the framework of which the derivation from hypotext to hypertext is both forceful (an entire B work comes from an entire A work) and-more or less-officially admitted. What hypotext is in literature, the same is the text of the precedent and/or the statute in the textual universe of the law, and the decision later on is the hypertext. See Genette, G.: Transztextualitás [Transtextuality]. Trans. Burján, M. Helikon, 42 (1996) 1-2, 82-90. Attila József was correct when he stated-the law: fabric. Whether it is "always bursting apart somewhere" or not. And this is how the poet becomes once again: the unacknowledged legislator of the world. 
The analysis of this interaction and dialogue could mostly be the territory of law and literature studies, but it seems, first, that this has only been a partial success so far, and second, that they have not managed to break through the ideas regarding the disciplinary separation of jurisprudence-and to a large extent, they have themselves to blame.

Besides struggling with the general problems of interdisciplinary studies, they are often stuck-as Jane B. Baron remarks ${ }^{27}$-with the same analytical scheme, which in most cases ends up being nothing more than a summary of the plot and the moral of literary works with a legal subject, providing a long line of obsolete or obsolete-prone interpretations. Moreover, not even these research efforts-despite the fact that the experience of marginalization is a constant reality for them in several forms-, are entirely devoid of a gesture of exclusion, generally described-when speaking of interdisciplinary approaches-as "colonization" by Jack M. Balkin. One discipline tries to use for its own purposes the perspectives, tools and methods of another, without showing real interest in commencing an actual dialogue. ${ }^{28}$ Even legal science and legal theory with an affinity for literature approaches the question with an eye to what it is that lawyers can hope from studying literature (and its theories), ${ }^{29}$ but this questioning does not work the other way aroundmeaning, what it is that the study of legal texts and through them legal science and jurisprudence in general could offer to literary scholars. And I believe that this is one of the main reasons why there has been no creative dialogue between the representatives of the two fields of research so far, ${ }^{30}$ and this is also the basis of those viewpoints that-no more than three and a half decades after its birth (or renaissance)-talk of the "death of law and literature". 31

27 Baron, J. B.: Law, Literature and the Problem of Interdisciplinarity. Yale Law Journal, 108 (1998) 5, 1059. István H. Szilágyi also talks about this problem in his work on the result of law and literature studies. H. Szilágyi, I.: Jog - Irodalom [Law-Literature]. In: Jog - Irodalom [LawLiterature]. Szeged, 2010. 89-120.

28 Balkin, J. M.: Interdisciplinarity as Colonization. Washington and Lee Law Review, 53 (1996), 949.

29 See also the program-defining study of James Boyd White: White, J. B.: What Can a Lawyer Learn From Literature? Harvard Law Review, 102 (1989), 2014.

${ }^{30}$ It is an entirely separate issue why most literary scholars-with the exception of Fish, Ferguson, James Boyd White and a few other great names-do not discover on their own the examination of the texts of the law as a possible area of interdisciplinary studies, but I believe that the dialogue should be commenced by lawyers, primarily because it seems that from this side of the field the evidence of the frequent contact between the two bodies of text is more visible, as the legal texts have always been more specific and aimed at a particular meaning, and especially in the era of modernity literary texts "absorb" the legal ones or play on them and it's not the other way around (as opposed to the Bible, for instance, where the religious-literary text included the legal one).

${ }^{31}$ Heald, P. J.: The Death Of Law and Literature: An Optimistic Eulogy. The Comparatist, 33 (2009), 20. Adding that I deeply disagree with Heald's-in this part optimistic-final conclusion (as well as other conclusions he makes in his work) that law and literature studies can only have a future of any note if the main product of these studies is the application of their moral interpretations of literary works in real life legal decision-making. 


\section{So what?-a short program speech-}

"He spoke. And drank rapidly a glass of water" E. E. Cummings ${ }^{32}$

It could be different. There have been several initiatives-partly conceived as intertextual in their nature-that, if continued, could deepen the dialogue between the two disciplines. Besides the approaches applied by Robert Cover and Robert A. Ferguson-which explore the interaction and interdependence between law and narrated stories, and legal and literary activity and thought process-the research of Theodore Ziolkowski is one that manages to successfully combine the perspectives of the history of law and literature, sociology of law and literature and theory of law and literature, mixing it with observations of the history of ideas, thus opening the possibility for all the representatives of these research areas to get involved in the discourse. Ziolowski examines, in essence, how the connection between law and literature arches through historic times, with special regard to those in which law entered a crisis to some extent or reached a turning point, and how this reflects in the literary works of the era, from ancient tragedies and eposes through the Icelandic sagas, the medieval German and French fables and the Elizabethan English dramas to the 19th-20th century novel. What really matters from all this-with respect to the objectives of the present writing-is this: the process. Ziolkowski's interpretations are of a double nature: first, as the reality-referential interpretations of the literary works of a certain era, they show how contemporary literary works present the dilemmas of the legal life-its historic practice and theory-of the era in question; second, searching for textual proofs-and finding these-they prove that the era's legal texts did indeed shape the text of these works. So: on the one hand-in the spirit of referentiality-we can find the fundamentals of such historical legal and literary sociological examinations that can be built on by legal historians, legal sociologists and legal theorists; on the other hand we can witness such an intertextual investigation that may be practiced by literary scholars as well. ${ }^{33}$

I find similarly double-natured those examinations-or more precisely: the possibilities therein-that form a part of socio-legal document-analysis executed by the sociology of law. Document-analysis-be it legal or non-legal documents, as in the case of the latter, literary works, press news and court reports, a product of the fine arts, films, or other products of popular culture ${ }^{34}$ (for instance, song lyrics) ${ }^{35}$-as a part of legal sociology examines primarily

32 E. E. Cummings: “next to of course god america i”. In: Complete Poems 1904-1962. New York (NY), 1994. 267.

33 Ziolkowski does not detail this in the same way, but I find that his analysis follows a similar pattern. The German comparatist author finds his own research in subject-matter to be similar to "law and literature" studies, but with regards to emphasis and objectives (in part) to be different and uses the "literature and law" denomination for those. With regards to difference in emphasis, he remarks that his approach is much more historic than theoretical, and he does not wish to read the dilemmas of neither the modern legal practice, nor the contemporary theory of law into the works of long gone times. His objective is to reconstruct the original legal, legal and socio-historic context of the studied literary works. Thus: his interest is "more substantive than rhetoric" in nature, with special attention paid to the traces of confrontations and conflicts between contemporary law and morals. Ziolkowski, T.: The Mirror of Justice: Literary Reflections of Legal Crisis. Note 8 above, xi-xii.

34 Sherwin, R. K.: When Law Goes Pop. Chicago-London, 2000.

35 For example: Armstrong, E. G.: Gangsta Misogyny: A Content Analysis of the Portrayals of Violence Against Women in Rap Music, 1987-1993. Journal of Criminal Justice and Popular 
the reality-relevance of the above-mentioned, that is, what kind of image they broadcast of law, jurisprudence, the legal profession or the perceptions members of society harbor with regards to these. ${ }^{36}$ Nothing forecloses, however, the possibility that these analyses could from time to time become intertextual in nature: in other words-now applying the experiences of sociolinguistics and the sociology of language ${ }^{37}$-by reading together legal and literary texts they can study and show us how society affects language (analogously the legal and the literary language) and the language use of its members, or how language (in this case: the mutually influential legal and literary language) affects society.

\section{Conclusion-even shorter}

So: to establish mutual contact between the legal and literary sciences, the partial rehabilitation of the referential interpretations of relevant literary works is not the single option. The-for the moment-dominant trends of contemporary literary thinking seem capable of being in sync more easily with those jurisprudential examinations that start off on the path of intertextuality, that is, consider as their primary task the exploration of the connections and specific forms of such connections of those legal and literary works that influence one another. The obvious purpose of these studies is to make sure that lawyers could also provide important lessons for literary scholars, and thus make the interest (once again) mutual and make the present dialogue more intensive between the advocates of the two fields. This would be the kind of dialogue that is well deserved by the historic connection between law and literature.

Culture, 8 (2001) 2, 96-126.

${ }^{36}$ Based on Jean Carbonnier's work, a summary in Hungarian language of these studies can be found in Zombor, F.: Dokumentumelemzés [Document-analysis]. In: Badó, A. et al.: Bevezetés a jogszociológiába [Introduction to the sociology of law]. Miskolc, 1997. 99-112., and H. Szilágyi: op. cit. 99-100.

37 See Kiss, J.: Társadalom és nyelvhasználat. Szociolingvisztikai alapfogalmak [Society and Use of Language. Socio-linguistic premises]. Budapest, 2002; Wardhaugh, R.: Introduction to Sociolinguistics. Oxford, 1997. On an added note: for these types of socio-legal documentary analysis I find it important that they should dispose of a literary approach that is at least compatible with the perspectives of contemporary literary studies; and they should leave the magic circle of the romantic genius aesthetics, in which writers and poets are portrayed as seers and prophets, as geniuses, who grab the "matter at hand" with the "instinctiveness of poetic geniality". The origins of exceptional linguistic competencies are of course impossible to explain, but Dickens and Kafka (and the others as well) were professionals. See also Zombor, F.: op. cit. 110. 